\title{
Tax Planning to "Contract for Labor Only" in the Construction Industry after VAT Comprehensive Expansion
}

\author{
Shuyu Peng \\ Oxbridge College, Kunming University of Science and Technology, Kunming, Yunnan, 650106
}

Keywords: VAT Comprehensive Expansion; Tax Planning; "Contract for Labor Only"; Construction Industry

\begin{abstract}
With the comprehensive expansion of value-added tax, China's construction industry, real estate industry, living services, financial industry has ended the payment of business tax since May 1 2016. The construction industry is undoubtedly the most changeable and far-reaching industry in the process of the expansion of VAT. Because the business model is multifaceted, the structure of the construction industry is complex as well. There are many subsidiaries, branches, divided project departments involving the longer management benefits chain. Multi-level management mode increases tax management costs and potential tax risks and the excessive burden of previous business tax; the old concept cannot disappear immediately. So the construction industry's tax risk will continue to erupt. After VAT expansion, the construction tax rate suddenly increased from 3\% of the past business tax to $11 \%$ of VAT, even worse, whether the construction enterprise can obtain VAT invoices to deduct the input tax still remains to be resolved. Tax rate and invoice issues will undoubtedly bring a lot of tax-related problems to the construction industry. Fortunately, the tax policy also gives construction industry some special situations which can be taxed with a simple method including the method of contract for labor only, contract for materials and labor, the old projects (the construction project before April 30, 2016 of the commencement date of the contract), which can be applied to 3\% VAT, but at this time must not deduct the input tax. This paper mainly aims at the method of "contract for labor only", which can choose the simple method of tax calculation, and puts forward some tax-related planning methods to the construction enterprises after the VAT expansion, hoping to help the construction enterprises to avoid the tax reasonably.
\end{abstract}

\section{Introduction}

In the way of the "contract for labor only", the construction enterprises do not purchase the materials required for the construction work or only buy part of the auxiliary materials, the simple manual labor service is provided, and the labor fee, management fee and other non material fees are charged. If the construction enterprises do not choose to tax according to the simple method, and choose to pay VAT by $11 \%$ of the VAT rate, in this case, if there is no corresponding sufficient value-added tax invoices to offset the input tax, it is bound to cause the construction enterprises in the way of the "contract for labor only" heavier tax burden aggravating enterprise cash flow to a certain extent stranded. It is more unfavorable to support the promotion of division of labor and promote the development of the industry. Is it necessary to choose a simple method for the construction industry that uses the way of "contract for labor only"? How the construction enterprises adopting the method of "contract for labor only" are supposed to choose the way of tax assessment with the new situation, and how to avoid tax reasonable combining the policy changed?

\section{Analysis of the choice of the method for construction company calculating VAT}

According to The regulation of relevant matters of the pilot for changing the business tax to VAT, as prescribed in paragraph 1 (7) of the first article:" the general taxpayer adopting the method of "contract for labor only" can elect in alternative to apply the simple way to tax." The document does not demand the taxpayers adopting simple method, but the taxpayers can choose to use by themselves, which is the construction company may elect in alternative to apply the simple method, 
also choose general way. If the construction enterprises choose simple method, then cannot deduct the input tax. Are the construction enterprises supposed to choose simple method to decrease the losses because of the insufficient input tax deductible? The answer is no. Actually, although they basically do not advocate the vital material purchasing, there will be little materials or auxiliary materials to buy. What kind of way can reduce the tax burden? We use the critical point of the tax burden assuming the tax calculated is the same either in the general method or simple method, applicable tax rate is $11 \%$ of the construction industry in general way, tax rate is $3 \%$ in easy way. Assumes that the price of the project including VAT is A adopting the method of "contract for labor only", construction company shall pay VAT $=A * 11 \% \div(1+11 \%)$ - input tax of construction company purchasing accessories $=9.91 \% * \mathrm{~A}$ - input tax of construction company purchasing accessories in the general tax mode; Under the simple method, construction company's VAT payable $=\mathrm{A} * 3 \% \div(1+3 \%)=2.91 \% * \mathrm{~A}$. Then we assume that the tax burden is the same in two methods, deduce the formula of $9.91 \% * A$ - input tax of construction company purchasing accessories $=2.91 \%$ $*$ A. With three formulas input tax of construction company purchasing accessories $=7 \% * \mathrm{~A}$. Normally, applicable tax rate of the construction company purchasing accessories is $17 \%$ (rarely involve low tax items, hypothesis based on common goods in building industry), input tax of construction company purchasing accessories = input tax including VAT of construction company purchasing accessories $* 17 \% \div(1+17 \%)=7 \% *$ A. The last critical point is deduced, input tax including VAT of construction company purchasing accessories $=48.18 \% * \mathrm{~A}$.

The core of construction company electing method to tax with the method of "contract for labor only" is construction company purchasing accessories more than $48.18 \%$ of the total project price VAT included or not. When the price of construction company purchasing accessories VAT inclued is over $48.18 \%$ *the total price, select general method; otherwise chose simple method.

\section{Case analysis}

Beijing Jian'an Construction Company is a general VAT taxpayer. On September 16, 2017 undertook project X with the method of "contract for labor only". On October 15, the custermer paid the 5.55 million yuan including VAT, the cost of this phrase for 2.9 million yuan (including the amount of RMB 1.9 million which is on VAT invoice for materials, power obtaining). What kind of way can reduce the tax burden? If Beijing Jian'an Construction Company chooses simple method, the input tax can't be deducted, with sales multiplied by the levy rates directly. At this point the VAT payable is 5,550,000 / $(1+3 \%) * 3 \%=161,700$ yuan. However, under the general method, the VAT payable $=5,550,000 /(1+11 \%) * 11 \%-1,900,000 * 17 \%=227,000$ yuan. Conclusion: when the total of purchasing materials and power including VAT is $2,223,000[1,900,000 *(1+$ $17 \%)]<2,674,000$ [48.18\% * the price of the project including VAT 5.55 million], choose simple method with 65, 300 yuan VAT saved (RMB 227,000- RMB 161,700).

Another case, when the amount of buying material, power, etc. on value-added tax invoices is larger, assuming that Beijing Jian'an Construction Company is a general VAT taxpayer. On September 2, 2017 it undertook project Y with the method of "contract for labor only". On October 1, the custermer paid the 5.55 million yuan including VAT, the cost of this phrase for 2.9 million yuan (including the amount of RMB 2.7 million which is on VAT invoice for materials, power obtaining). If construction company chooses simple method, the tax payable $=$ sales $*$ levy rates, value-added tax is 5,550,000 / $(1+3 \%) * 3 \%=161,700$ yuan. However, under the general method, VAT $=5,550,000 /(1+11 \%) * 11 \%-2,700,000 * 17 \%=91,000$ yuan. Conclusion: when the total of purchasing materials and power including VAT is 3,159,000 [2,700,000* $(1+17 \%)]>2,674,000$ [48.18\% * the price of the project including VAT 5.55 million], at this time choose general method saving 70,700 yuan of value-added tax (RMB 161,700- RMB 91,000) than that of simple method.

\section{Project subcontracting and organization flattening}

If taxpayers adopting the method of "contract for labor only" don't choose simple and easy way to tax, construction companies will face up to $11 \%$ of the value-added tax rates. The amount of the 
enterprise tax burden would depend on whether they can obtain corresponding input tax with value-added tax invoices to deduct. Due to the particularity of the construction industry, many suppliers are individuals; sand, stone, wood, cement and services they supplied are difficult to issue VAT invoices. Construction enterprises can't offset the input tax, and therefore will face a tax rate of $11 \%$. In this case, the construction enterprise can try subcontracting especially those not being able to deduct input tax project; construction enterprise can declare value added tax on the balance after the subcontracting. The invoice issued by the subcontractors in these small projects, and thus solves the losses partly because of the lack of upstream suppliers' VAT invoices. Complex internal organization structure, long chain management mode in large construction enterprise leads to possible the tax risk. So construction enterprise group should shift this complex and muti-level organization structure, reduce management departments and hierarchy appropriately, compress processing chain, gradually form a super compact and effective decision-making organization which is the non-pyramid of flating management pattern in order to cut the tax risk. Breakthrough point can be the seperating of professional business project, establish a subsidiary company of professional application, which can do the independent accounting and declaring.

\section{Change and reengineer of business process}

The construction site of some construction enterprises often use preformed unit which have standard module and size such as cement cover, reinforced concrete floats, steel structure, etc. If they are directly provided by the subcontractor, construction enterprises can only get $11 \%$ of the value-added tax invoices. If we change and reengineer the business process, which seperates the raw materials purchasing and prefabricated parts processing services. Construction enterprise can obtain $17 \%$ of the input tax of the raw material and subcontract labor input tax of $11 \%$. It can be seen that after the business process reengineering, taxes had significantly lower. During the prosess of seperating, we need to consider the way of signing contrct. The contract can not be signed as a whole chunk, the purchase of raw materials and the subcontract labor contracts should be signed separately as far as possible in order to enjoy the input tax deduction behind the different tax rates respectively. If it is not able to divide, we also need to require the prices in the contrct are clear, and each situation is issued tax invoices for value-added tax individually.

\section{The use of financing lease}

When the price of construction company purchasing accessories VAT included is over $48.18 \%$ *the total price, construction company would select general method. Building enterprises need to find the input tax as much as possible to deduct. However, the construction industry is a capital-intensive industry which is different from other industries; usually the interest paid is enormous. But some interests cannot be offset in time, such as the capitalized interest, which will improve the overall tax burden of construction enterprises, which leads to a higher refinancing cost. Construction enterprises can try to change the financing pattern: the first choose machine equipment according to company demand, then purchase by financing lease company, financing lease company finally rent it for construction company. In this way, companies simply changed the loan financing behavior to financing lease behavior. The better thing is that it can obtain the invoices issued by financing lease companies to offset the input tax, avoid the disadvantages of loan interest been not able to offset the input tax in current period. Thus this siuation reduces construction enterprise group's overall tax burden, but also makes the company having the right to use the construction equipment without spending too much cost.

\section{The choice of supplier identity}

If the purchase price is the same, we are more inclined to choose suppliers who can issue invoices. The supliers construction companies met in reality could be general taxpayer, also small-scale taxpayer, and supply price is not the same. In this case, we will consider that the supply 
price of small-scale taxpayers is lower than the critical point or not, which can cover the losses of building enterprise because they can't get invoices of deduction of input tax. We assume that the material varieties, type, quality, etc., are consistent to the choice of construction companies.

\section{Conclusion}

The core of construction company electing method to tax with the method of "contract for labor only" is construction company purchasing accessories more than $48.18 \%$ of the total project price VAT included or not. When the price of construction company purchasing accessories VAT inclued is over $48.18 \%$ *the total price, select general method; otherwise chose simple method. Furthermore, project subcontracting and organization flattening, changing and reengineering of business process, the use of financing lease and the choice of supplier identity are significant methods to decrease the tax burden of construction company with the method of "contract for labor only".

\section{References}

[1] Relaxation efforts to improve the level of water environmental protection in Jiangsu [J]. Mass. 2017 (17)

[2] Liu Juan. Research on water resources utilization and water environment protection in China [J]. Building Materials and Decoration. 2017 (43)

[3] Chongyang Pipeline Project to cut off urban sewage out of urban water environment protection [J]. Water Supply and Drainage Dynamics. 2013 (05)

[4] Tao Kun. Recommendations for Enhancing Protection of Water Environment in Ma'anshan City [J]. Jiangdong Forum. 2016 (04) 